\title{
Syntheses of Isoxazoline-Carbocyclic Nucleosides and Their Antiviral Evaluation: A Standard Protocol
}

\author{
Paolo Quadrelli, ${ }^{1}$ Naiara Vazquez Martinez, ${ }^{1}$ Roberto Scrocchi, ${ }^{1}$ \\ Antonino Corsaro, ${ }^{2}$ and Venerando Pistarà ${ }^{2}$ \\ ${ }^{1}$ Dipartimento di Chimica, Università degli Studi di Pavia, Viale Taramelli 12, 27100 Pavia, Italy \\ ${ }^{2}$ Dipartimento di Scienze del Farmaco, Università degli Studi di Catania, Viale A. Doria 8, 95125 Catania, Italy
}

Correspondence should be addressed to Paolo Quadrelli; paolo.quadrelli@unipv.it

Received 20 June 2014; Accepted 18 September 2014; Published 30 October 2014

Academic Editor: Donatella Paolino

Copyright (C) 2014 Paolo Quadrelli et al. This is an open access article distributed under the Creative Commons Attribution License, which permits unrestricted use, distribution, and reproduction in any medium, provided the original work is properly cited.

\begin{abstract}
The current synthesis of racemic purine and pyrimidine isoxazoline-carbocyclic nucleosides is reported, detailing the key-steps for standard and reliable preparations. Improved yields were obtained by the proper tuning of the single synthetic steps, opening the way for the preparation of a variety of novel compounds. Some of the obtained compounds were also evaluated against a wide variety of DNA and RNA viruses including HIV. No specific antiviral activity was observed in the cases at hand. Novel compounds were prepared for future biological tests.
\end{abstract}

\section{Introduction}

Carbocyclic nucleosides (carbanucleosides) [1] are modified nucleosides [2] in which a methylene group has replaced the oxygen atom of the furanose ring [3]. Due to the absence of a glycosidic linkage, carbanucleosides are chemically more stable and not subjected to the phosphorylases that cleave the $\mathrm{N}$-glycosidic linkage in conventional nucleosides [4]. Many compounds of this class with potent and selective biological activity have been identified [5], including carbovir [6] $\mathbf{1}$ and abacavir [7] 2, which are currently used therapeutically as anti-HIV agents.

An important aspect of the anti-HIV therapy is the suppression of viral replication in the brain; in this regard an enhanced lipophilicity of potential drugs is likely to be advantageous. Recently, Vince and Hua [6] have reported the modification of the stavudine 3 by fusion of a benzene ring to the carbasugar, leading to analogue 4 [8]. This structural modification increases the lipophilicity (and hence the access to the central nervous system, a major reservoir of HIV) [9] while maintaining the rigidity imposed by the $\mathrm{C} 2$ ' $-\mathrm{C} 3$ ' double bond. Analogously, carbanucleosides in which an aromatic heterocycle is fused to the carbasugar of carbovir and abacavir have been prepared [10]. Five-membered heterocyclic rings such as a pyrazole [11] or isoxazoline [12] are often found in carbocyclic nucleosides [13] as expedients to tune up the lipophilicity or reduce the conformational flexibility of the carbocyclic moiety (Figure 1) [14].

Recently, we have reported the synthesis of carbocyclic nucleosides 5 containing a fused isoxazoline ring and lacking a methylene $\left(\mathrm{CH}_{2}\right)$ group in the side chain in the carbocyclic unit [12-14]. Nucleosides lacking a methylene group in the side chain have been reported and in some cases display reduced cytotoxicity [15]. The synthetic route that we have exploited, based on the hetero-Diels-Alder (HDA) cycloaddition of dienes with transient acyl nitroso moieties [16], affords "privileged structures" [17] for the synthesis of carbocyclic nucleosides [18].

However, some steps of the synthetic procedure for the linear construction of the nucleobases were problematic and not all of the synthesized compounds could be prepared on a suitable scale for biological tests. Because of these problems, at the beginning of our work, it was not possible to fully evaluate the biological activity of this class of nucleosides, and further structural modifications, necessary for an improved antiviral activity and for a better understanding of the structure-activity relationship (SAR), were sometimes forbidden. 
<smiles>Nc1nc2c(ncn2[C@H]2C=C[C@@H](CO)C2)c(=O)[nH]1</smiles>

1<smiles>Cc1cn([C@@H]2O[C@H](CO)c3ccccc32)c(=O)[nH]c1=O</smiles>

4
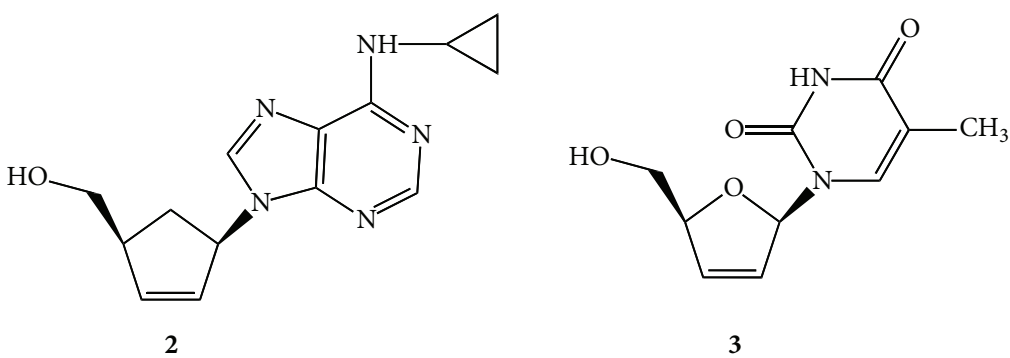

3

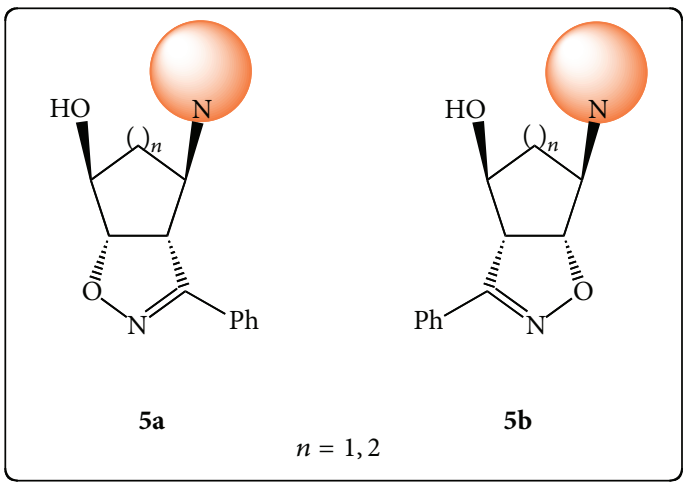

Figure 1
On pursuing our studies on the biological activity of carbanucleosides, we present here the improved synthetic procedure of compounds of type $5(n=1)$, amenable to a larger scale preparation and for the preparation of a variety of novel compounds. Their inhibitory activity against a wide range of DNA and RNA viruses, including HIV, is also reported and discussed.

\section{Results and Discussion}

2.1. Chemistry. The HDA cycloadduct N-benzoyl-2,3oxazanorborn-5-ene 8 was obtained from freshly distilled cyclopentadiene $\mathbf{6}$ ( 2 equivalents) that quantitatively trapped the nitrosocarbonyl benzene 7 generated in situ through the mild oxidation of benzonitrile oxide Ph-CNO (BNO) in $\mathrm{CH}_{2} \mathrm{Cl}_{2}$ with a slight excess (1.3 equivalents) of $\mathrm{N}$-methylmorpholine $N$-oxide (NMO) according to the published procedure (Scheme 1) $[18,19]$ in good yields $(73 \%)$. It is essential not to exceed with the NMO amounts in this preparation because a larger excess of the oxidant could be detrimental for the nitrosocarbonyl intermediate's life, since the $N$-oxide could add the intermediate and promote its decomposition $[16,18,19]$. In Scheme 1 the decomposition pathway is sketched. Nitrosocarbonyls are in fact short-living species, just $180 \mu$ s as reported by Cohen and coworkers [20] and, if not instantly trapped, can add the excess NMO to give the intermediate $\mathbf{7} \mathbf{i}$ that evolves to add nucleophilic species which can be present in the reaction mixtures even in small amounts to afford $\mathrm{N}$-methylmorfoline, $\mathrm{N}_{2} \mathrm{O}$, and the adduct between the benzoyl group and the nucleophile $\mathrm{Nu}$ (in case of water, benzoic acid) [21].
The $N$-benzoyl-2,3-oxazanorborn-5-ene 8 was found to be an excellent dipolarophile towards BNO addition, affording the two regioisomeric cycloadducts $\mathbf{9 a}$ and $\mathbf{9 b}$ which were easily isolated in quantitative yields by chromatographic separation in a $3: 2$ regioisomeric ratio $[18,19]$. A proper tuning of the subsequent synthetic steps had to be done for the scale-up necessary for the synthesis of nucleosides in the due amount for the biological tests.

The ease detachment of the benzoyl group from the cycloadducts $\mathbf{9 a}$, b was achieved through $\mathrm{NaOH} / \mathrm{MeOH}$ treatment at room temperature for $24 \mathrm{~h}$, affording the fairly stable hydroxylamines 10a,b. The careful revision of the alkaline hydrolysis allowed for improved protocols for this step that was forced to take place in quantitative yields $(+20-30 \%$ with respect to the previous method) [19]. The reaction has been conducted by adding a slight excess (1.2 equivalents) of $\mathrm{NaOH}$, added portionwise in $2-3 \mathrm{~h}$, to a methanol solution of cycloadducts $\mathbf{9 a}, \mathbf{b}$, stirred at room temperature until complete disappearance of the starting materials. Extended reaction times (from 12 to $24 \mathrm{~h}$ ) ensured the quantitative transformation of the HDA cycloadducts $\mathbf{9 a}, \mathbf{b}$ into the desired hydroxylamines $\mathbf{1 0 a}, \mathbf{b}$. These compounds were previously fully characterized [19] and found completely stable in the solid phase but they do not survive for long when left in solution and decompose in several uncharacterized products in miserable yields.

The hydrogenolytic cleavage of the $\mathrm{N}-\mathrm{O}$ bond of the hydroxylamine $\mathbf{1 0 a}, \mathbf{b}$ has been also improved and takes place also quantitatively $(+30-40 \%$ with respect to the previous method) [19] by performing the reaction with $\mathrm{Pd} / \mathrm{C} 10 \%$ in ethyl acetate at room temperature for $3 \mathrm{~h}$ (extended time). Hence, the aminols 11a,b were obtained and found 


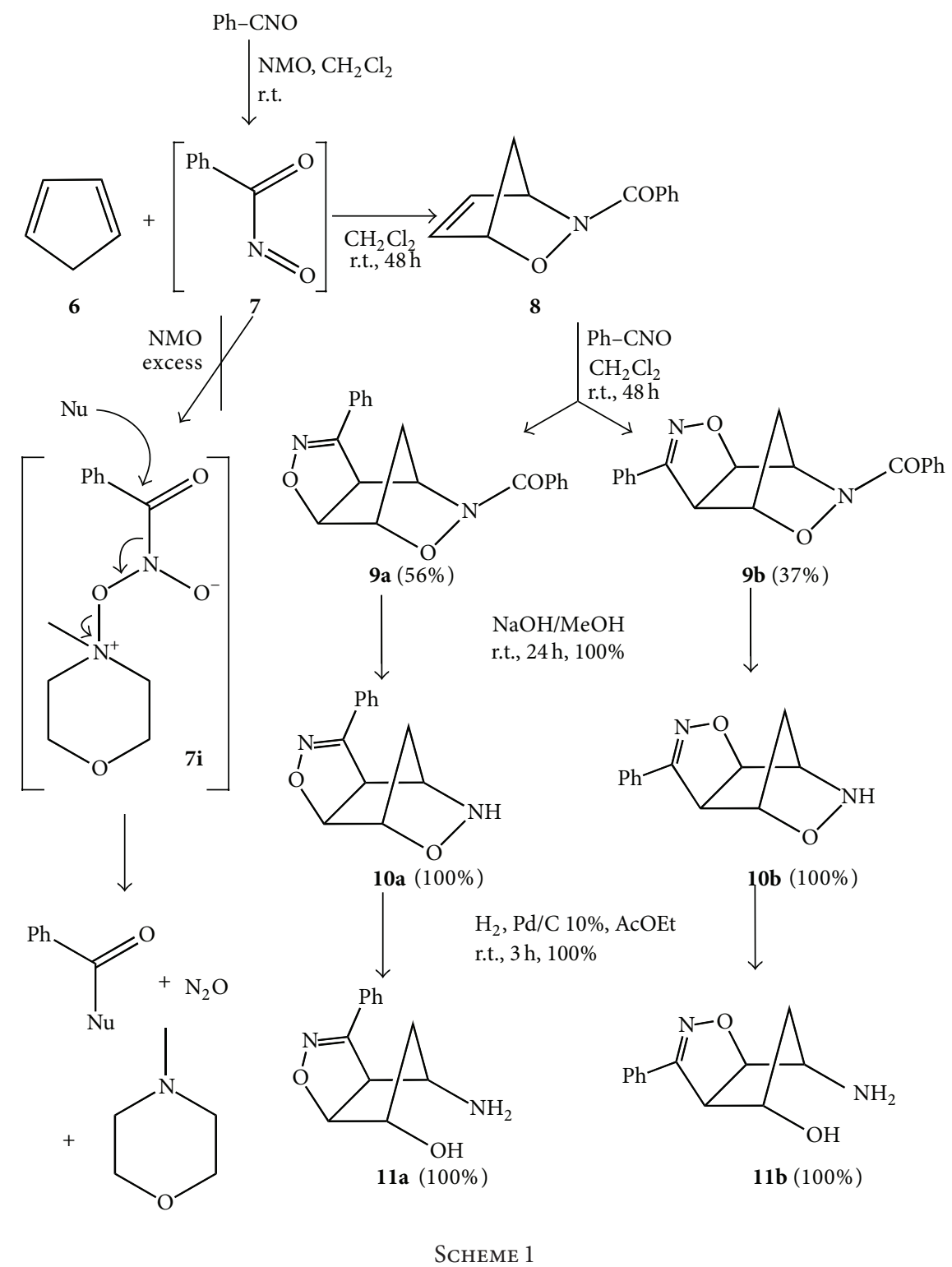

identical with authentic samples previously prepared [19]. The regioisomeric aminols $\mathbf{1 1 a}, \mathbf{b}$ were then submitted to the transformations into the desired nor-nucleosides [13] through linear construction of the purine and pyrimidine rings [22].

The synthesis of the purine-nucleosides 13 requires the two steps sketched in the Scheme 2.

The first one is the condensation of the regioisomeric aminols 11a,b with the 5-amino-4,6-dichloropyrimidine to give the pyrimidine derivatives of type $\mathbf{1 2 a} \mathbf{a}, \mathbf{b}$. This condensation is indeed the most difficult step in the synthesis, which attained only low yields (around 50\%) in the previously reported preparations [13]. Better yields of 12a,b were achieved by increasing the reaction temperature gradually up to the boiling point of the solvent. An excess ( 2 equivalents) of the 5-amino-4,6-dichloropyrimidine was added to a $n$ $\mathrm{BuOH}$ solution of the aminols 11a,b in the presence of 5 equivalents of $i-\operatorname{Pr}_{2} \mathrm{EtN}$. The solutions are stirred at room temperature for $1 \mathrm{~h}$ and a gradual increase of temperature at the boiling point of $n-\mathrm{BuOH}\left(117^{\circ} \mathrm{C}\right)$ was conducted in $1 \mathrm{~h}$ in sealed tubes. After $48 \mathrm{~h}$ under these conditions the $n-\mathrm{BuOH}$ was removed at reduced pressure and the residues were taken up with dichloromethane (DCM) and washed with water. The residues, obtained by evaporation of the DCM, were submitted to chromatographic separation to isolate, from the excess of reagent, the pyrimidine derivatives $\mathbf{1 2 a} \mathbf{a}, \mathbf{b}$ in $79 \%$ yields for both regioisomeric compounds. Any attempt to shorten the reaction time by using microwave irradiation instead of conventional heating unfortunately failed. The structures of compounds $\mathbf{1 2 a}, \mathbf{b}$ were confirmed through comparison with authentic samples and spectroscopic analyses. For NMR details we send back to [13].

The conversion of the pyrimidine derivatives $\mathbf{1 2 a}, \mathbf{b}$ into the chloropurine compounds $\mathbf{1 3} \mathbf{a}, \mathbf{b}$, which was found previously somewhat problematic due to incomplete ring closure and instability of final products [13], has been also simplified. 


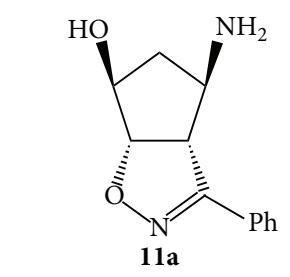<smiles>N[C@H]1C[C@@H](O)[C@H]2ON=C(c3ccccc3)[C@H]12</smiles><smiles>Nc1c(Cl)ncnc1N[C@@H]1C[C@H](O)[C@H]2ON=C(c3ccccc3)[C@H]21</smiles><smiles>Nc1c(Cl)ncnc1N[C@@H]1C[C@H](O)[C@H]2C(c3ccccc3)=NO[C@H]12</smiles><smiles>CC(C)(C)c1noc2c1[C@@H]1[C@H]2[C@@H](n2cnc3c(Cl)ncnc32)C[C@H]1O</smiles><smiles>[13CH3]N1O[C@H]2[C@@H]([C@@H](O)C[C@H]2n2cnc3c(Cl)ncnc32)[C@H]1c1ccccc1</smiles><smiles>[R12]Nc1ncnc2c1ncn2[C@@H]1C[C@H](O)[C@H]2ON=C(c3ccccc3)[C@H]21</smiles><smiles>[R17]Nc1ncnc2c1ncn2[C@@H]1C[C@H](O)[C@H]2C(c3ccccc3)=NO[C@H]21</smiles>

(a) 5-Amino-4,6-dichloropyrimidine ( 2 eq.), $i \operatorname{Pr}_{2} \operatorname{EtN}$ (5 eq.), $n \mathrm{BuOH}, 117^{\circ} \mathrm{C}, 48 \mathrm{~h}$

(b) $\mathrm{HC}(\mathrm{EtO})_{3}, p \mathrm{TsOH}$, r.t., $6 \mathrm{~d}$

(c) $\mathrm{RR}^{\prime} \mathrm{NH}, \mathrm{MeOH}, 50^{\circ} \mathrm{C}, 24 \mathrm{~h}$

SCHEME 2

Solutions of 12a,b in ethyl orthoformate were stirred at room temperature until the pyrimidine derivatives were completely converted into the formylated compounds (monitoring by TLC, $5-7 \mathrm{~h}$ ) and at this time a catalytic amount of $p \mathrm{TsOH}$ was added and stirring continued for 5 days. On applying the frequently reported methods [23] using triethyl orthoformate in the presence of $37 \% \mathrm{HCl}$ at r.t., no condensation took place and the starting materials were recovered unchanged after the suggested work-up. Harsher conditions [24] sometimes allow for the obtaining of the desired product albeit in poor yields, but in most of the cases the starting material decomposed. The rather tedious work-up procedure (orthoformate evaporation, addition of $\mathrm{Et}_{3} \mathrm{~N}$ to a $\mathrm{CHCl}_{3}$ solution and stirring for $24 \mathrm{~h}$, washing with water and drying, evaporation of the $\mathrm{CHCl}_{3}$, residues taken up with EtOAc and stirring for several hours, evaporation of the solvent, and chromatographic separation) has been simplified by adding water to the orthoformate solutions 
<smiles>Nc1ncnc2c1ncn2[C@@H]1C[C@H](O)[C@H]2ON=C(c3ccccc3)[C@H]21</smiles><smiles>[R]c1cn([C@@H]2C[C@H](O)[C@H]3ON=C(c4ccccc4)[C@H]32)c(=O)[nH]c1=O</smiles>
$16 \mathbf{a}$

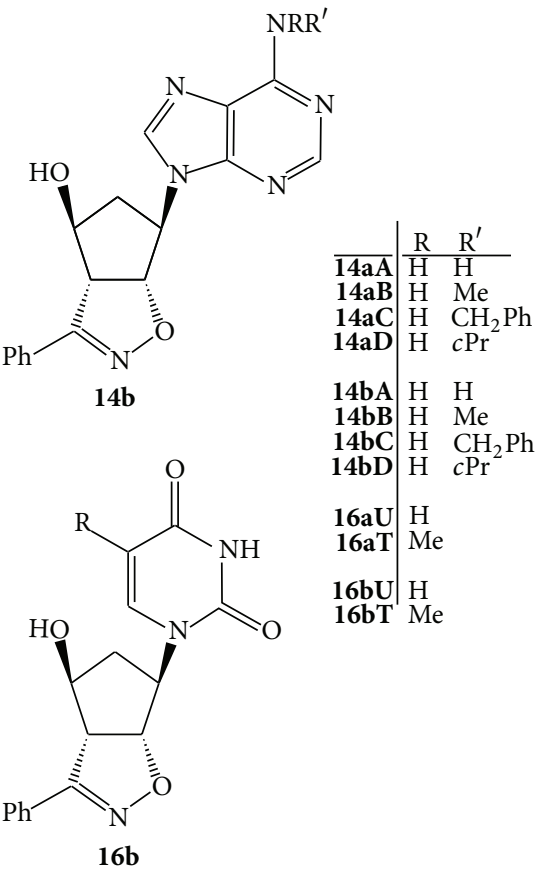

Figure 2 to hydrolyze the excess orthoformate and the formylated intermediates and allowing the solution to stand at room temperature for $24 \mathrm{~h}$. Extraction with DCM allowed isolating in quantitative yields $(+10 \%)$ the chloropurine derivatives 13a,b which have been characterized spectroscopically and found identical with authentic samples (see [13] for NMR details).

The final chlorine replacement method with selected amines did not require any revision since the substitution occurs with high yields and was conducted as previously described [13] upon heating $\mathrm{MeOH}$ solutions of $\mathbf{1 3 a}, \mathbf{b}$ at $50^{\circ} \mathrm{C}$ in the presence of an excess $\mathrm{NH}_{3}$ or some primary amines (methyl-, benzyl-, and cyclopropyl-amine) affording the adenine derivatives $\mathbf{1 4 a}, \mathbf{b}$ in more than $92 \%$ yields (HPLC) which have been submitted to the biological tests (Figure 2).

However, this type of derivatization is not applicable to all the groups to be inserted as nucleophiles. Alcoholic solvents remain the base to dissolve properly the chlorine-nucleosides but the presence of a cosolvent has to be evaluated, accordingly [25]. This is the case of the insertion of a thio-group ( $\mathrm{SH}$ ) in place of the chlorine atom (Scheme 3).

The chlorine-nucleosides $13 \mathbf{a}, \mathbf{b}$ were dissolved in an hydroalcoholic solution in the presence of excess $\mathrm{Na}_{2} \mathrm{~S}$ and the mixture was heated at reflux for a couple of hours. Upon neutralization with acetic acid 10\% and cooling, the thio-derivatives $\mathbf{1 4 a}, \mathbf{b S}$ crystallized and were easily filtrated (14a,bS, $89 \%$ and $87 \%$ yields, resp.). Their structures rely upon the corresponding analytical and spectroscopic data and this characterization evidenced the presence of the tautomeric equilibrium between the two forms reported in Scheme 3 .
The tautomeric ratio varied upon the polarity of the solvent and Table 1 reports the ratios determined in representative polar solvents and the chemical shifts of the main protons of the structures reported. The ratios were determined through NMR spectroscopic studies by measuring the integral ratios of the $\mathrm{CH}=\mathrm{N}$ sharp singlets in the solvents reported and the attribution to the two tautomers of the different groups of signals was done upon COSY experiments.

Upon comparison of the NMR spectroscopic data of compounds 14a,bS and the NMR data reported in literature [26], it was possible to attribute unequivocally the structures of the two tautomeric forms for both the regioisomers [27]. It is known in fact that the thioxo form II is greatly stabilized in aqueous solution [28]. The NMR data in our hands suggest that the form II is the major component in some of the mixtures and the ratios can be reverted by changing the solvent. The equilibrium is slow and, besides the aromatic signals of the phenyl groups, which are coincident, most of the other signals both from the purine heterocyclic ring and the isoxazoline-cyclopentanol moiety differ remarkably allowing for the clear resolution of the two tautomers.

A different behaviour is noticeable between the two regioisomers $14 \mathrm{aS}$ and $\mathbf{1 4 b S}$. In deuterated acetone, regioisomer $14 \mathrm{aS}$ is mainly present as the thioxo tautomer II whose proton signals are downfield shifted with respect to tautomer I in nice keeping with the observations reported in literature for thiopurine derivatives [28]. The two tautomers equally coexist in deuterated methanol while in DMSO the ratio is remarkably reverted in favour of the mercapto form I. This is presumably due to the known ability of DMSO to establish 
TABLE 1: Tautomeric ratios and chemical shifts for compounds 14a,bS.

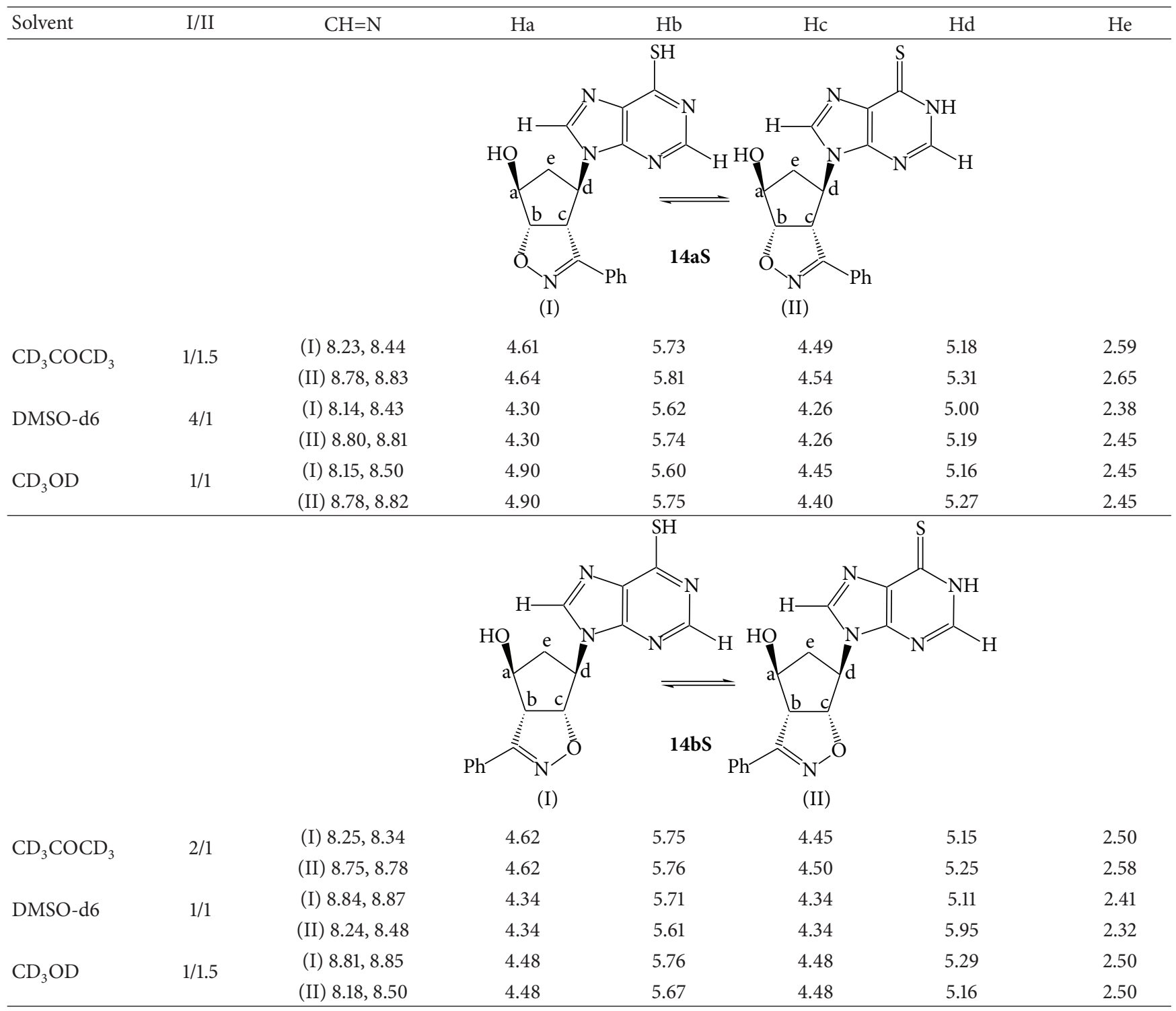

$\mathrm{H}$-bonds, in this case with the $\mathrm{SH}$ group, hence stabilizing the tautomer $\mathbf{I}$.

The second regioisomer $\mathbf{1 4 b S}$ shows a diminished variation of the tautomeric ratio as a function of the solvent changes. Both in DMSO and deuterated methanol the ratios are close to $1 / 1$. Only in acetone tautomer I is twice the other.

The stereoisomeric aminols 11a,b were also converted into the uracil and thymine nucleosides. Among the several methods reported in literature for the synthesis of pyrimidines [29] and in particular those involving the formation of two bonds suitable for uracils preparation, the linear construction of these heterocycles [30] through condensation of aminols 11a,b with the appropriate isocyanates was preferred because of its wide applications in a variety of substrates and experimental conditions as well as for the excellent results achieved [31].
The synthetic route to uracil and thymine nucleosides involves the steps illustrated in Scheme 4 and started with the preliminary preparation of the isocyanates whose quality and purity strongly determine the yields of the final compounds. The condensations of the isocyanates with aminols 11a,b were performed at $-20^{\circ} \mathrm{C}$ in anhydrous DMF solutions and the reactions left at room temperature for $12 \mathrm{~h}$. The urea adducts $\mathbf{1 5 a}$, b were obtained in $82 \%$ yields and found identical with authentic samples previously prepared [13]. Cyclization of the ureas 15a,b took place smoothly upon gentle refluxing in $2 \mathrm{M} \mathrm{H}_{2} \mathrm{SO}_{4}$ solution for $3 \mathrm{~h}$. The uracil nucleosides 16Ua,b and the thymine analogues $\mathbf{1 6} \mathrm{Ta}, \mathbf{b}$ were isolated from these solutions after $\mathrm{pH}$ adjustment to 7 and extraction with dichloromethane. The yields of the cyclization steps were satisfactorily improved $(95 \%,+20 \%)$ and the structures confirmed through spectroscopic analyses. 


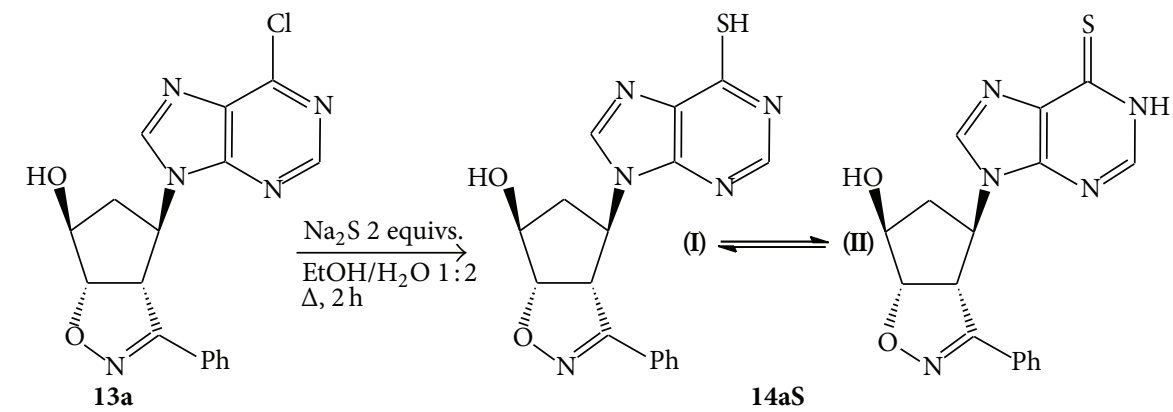

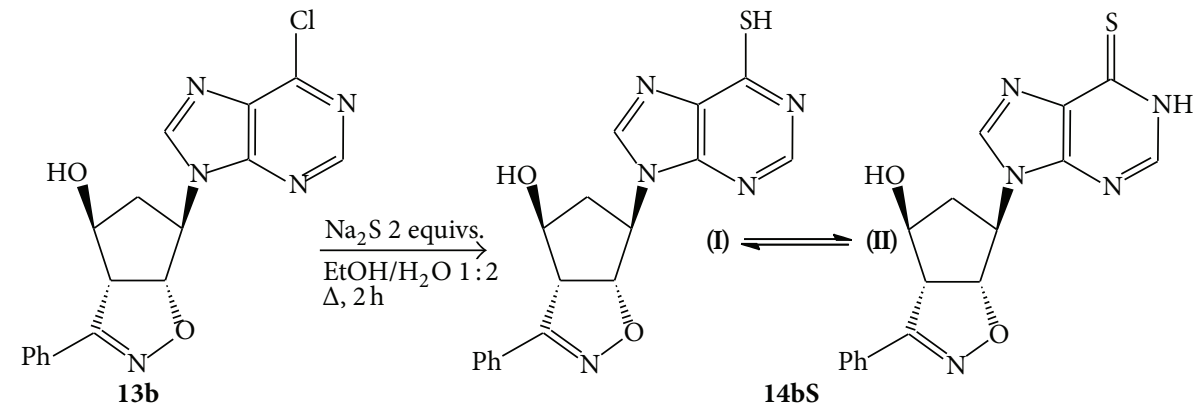

SCHEMe 3

The products were submitted to biological evaluation (Figure 2).

2.2. Antiviral Activity. Compounds $\mathbf{1 4 a}, \mathbf{b}$ and $\mathbf{1 6 a}, \mathbf{b}$ were evaluated for their inhibitory activity against a wide variety of viruses, including herpes simplex virus type 1 (HSV-1 (strain KOS) and $2 \mathrm{HSV}-2(\mathrm{G})$ ), vaccinia virus (VV), vesicular stomatitis virus (VSV), herpes simplex virus $1 \mathrm{TK}^{-}\left(\mathrm{ACV}^{\mathrm{r}}\right)$, parainfluenza-3 virus (PiV), reovirus-1 $(\mathrm{RV})$, sindbis virus (SV), coxsackie virus B4 (CV), Punta Toro virus (PTV), and respiratory syncytial virus (RSV).

The antiviral activity of the above-reported compounds was tested in vitro in HEL, HeLa, and Vero cells cultures, where appropriate, along with the reference antiviral compounds such as brivudine, ribavirin, acyclovir, ganciclovir, and (S)-DHPA. Results are, respectively, shown in Tables 2-4.

All synthesized compounds showed no specific antiviral effects; some differences between the regioisomeric nucleosides can be however noted. Regioisomers of type b, involving a phenyl group distal to the heterocyclic base, display better response than regioisomers of type a, which have proximal phenyl and heterocyclic base. If this indication will be confirmed in other cases, future syntheses will benefit of new efforts to orientate more regioselectively the preparation of new nucleosidic targets. Moreover, all compounds were evaluated for antiviral activity against HIV-1 (strain $\operatorname{III}_{\mathrm{B}}$ ) and HIV-2 (strain Rob) in MT-4 cell culture and none of these compounds showed inhibitory activity at concentration up to $400 \mu \mathrm{g} / \mathrm{mL}$.

The modest antiviral activity showed from these compounds could be likely linked to the lack of substrate activity for cellular and/or viral nucleoside kinases or alternatively the lack of recognition of the compounds by the viral DNA or RNA polymerases.

\section{Conclusions}

In conclusion, the synthesis of isoxazoline-carbocyclic nucleosides was properly tuned as well as improved and a variety of analogues were attained starting from the stereodefined heterocyclic aminols 11a,b. These latter ones are readily available through exo selective 1,3-dipolar cycloadditions of benzonitrile oxide to $N$-benzoyl-oxazanorbornene $\mathbf{8}$ and simple elaborations of the cycloadducts $\mathbf{9 a}, \mathbf{b}$. The stereodefined heterocyclic aminols 11a,b afford the carbocyclic skeleton for the linear construction of the purine type, uracil, and thymine moieties.

Compounds 14a,b and 16a,b were evaluated for their inhibitory activity against a wide variety of viruses through in vitro tests in HEL, HeLa, and Vero cells [32]. Modest antiviral activities were observed. In order to have more insights on the SAR [33] and to increase the antiviral activities of this class of nor-nucleosides their transformation into the corresponding nucleotide monophosphate analogue by esterification of secondary hydroxyl group into phosphonomethyl ether $(=\mathrm{P}$ $\left.(\mathrm{OH})_{2}-\mathrm{CH}_{2}-\mathrm{O}-\right)$, which is isosteric of phosphate group $(=\mathrm{P}$ $\left.(\mathrm{OH})_{2}-\mathrm{O}-\mathrm{CH}_{2}-\right)$, will be further performed [34].

The biological tests of the thio-derivatives are currently under evaluation. In view of the results obtained with the amino-derivatives, different targets for both the typologies of compounds have been chosen and the results will be accounted in future papers.

\section{Experimental}

All melting points are uncorrected. IR spectra (Nujol mulls) were recorded on a FT-IR Perkin-Elmer RX-1. ${ }^{1} \mathrm{H}$ - and ${ }^{13} \mathrm{C}$ NMR spectra were recorded on a Bruker AVANCE 300 in the specified deuterated solvents. Chemical shifts are 


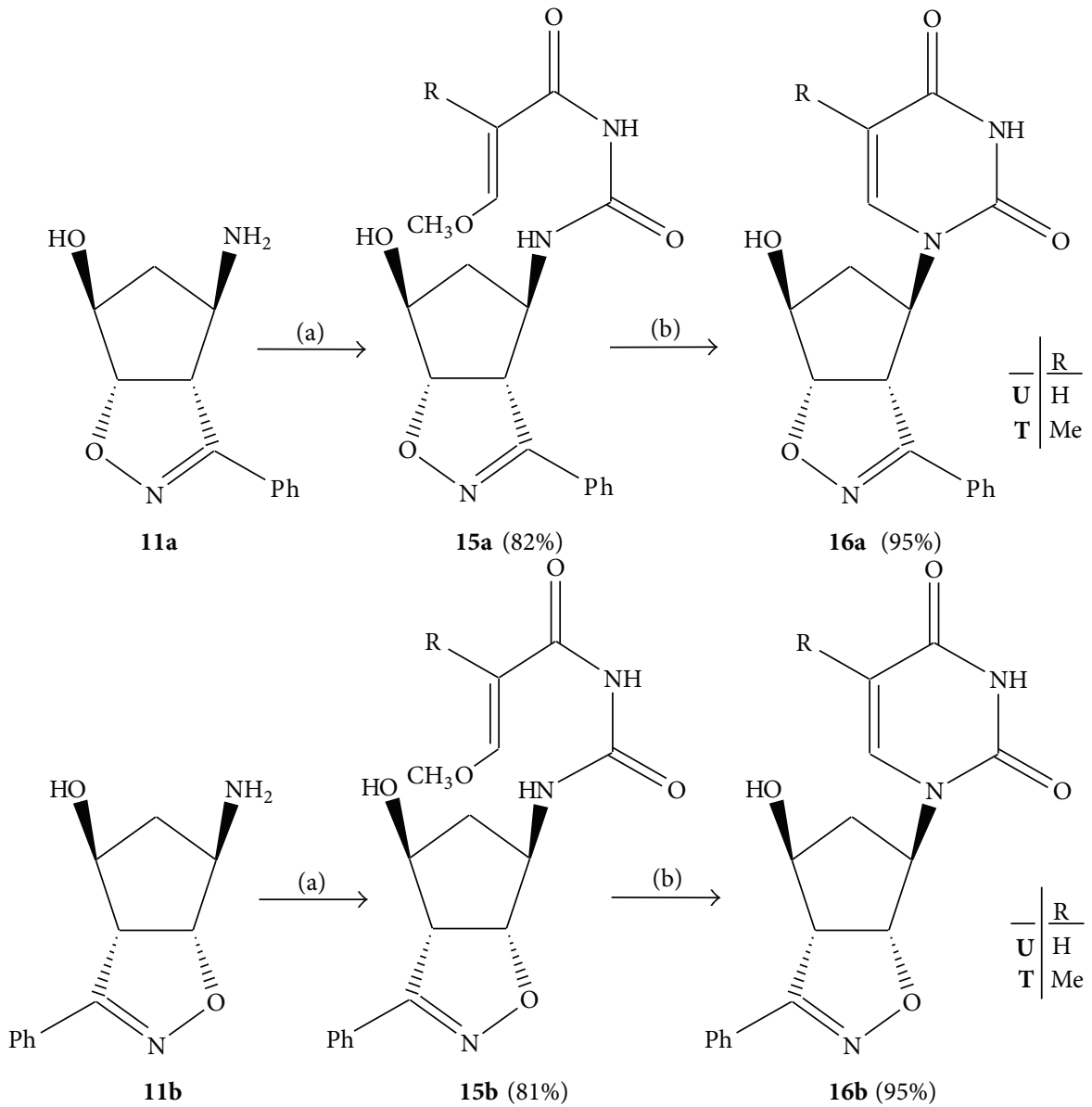

(a) $\mathrm{MeO}-\mathrm{CH}=\mathrm{C}(\mathrm{R})-\mathrm{CO}-\mathrm{NCO}$ (1.2 eq.), $\mathrm{MS} 4 \AA$, $\mathrm{DMF},-20^{\circ} \mathrm{C}$ to r.t., $12 \mathrm{~h}$

(b) $\mathrm{H}_{2} \mathrm{SO}_{4} 2 \mathrm{M}, \Delta, 3 \mathrm{~h}$

SCHEME 4

expressed in ppm from internal tetramethylsilane $(\delta)$. UVVis spectra were recorded on a UV Perkin-Elmer LAMBDA 16 spectrophotometer using acetonitrile as solvent. HPLC analyses were carried out by means of a WATERS 1525 instrument equipped with UV 2487 detector $(\lambda=266 \mathrm{~nm})$ both controlled by Breeze software and a RP C-18 Inertsil ODS-2 column; a mixture of $\mathrm{H}_{2} \mathrm{O} / \mathrm{CH}_{3} \mathrm{CN} 50 / 50$ was used as eluent. Column chromatography and tlc: silica gel $60(0.063-0.200 \mathrm{~mm})$ (Merck); eluent chloroform or chloroform/methanol $9: 1$. The identification of samples from different experiments was secured by mixed mps and superimposable IR spectra.

Materials. Regioisomeric aminols 11a,b were prepared through previously reported syntheses [19] by applying the modified protocols described in this paper to get the aminols in quantitative yields from the regioisomeric cycloadducts 9a,b.

4.1. Synthesis of the Pyrimidine Derivatives $\mathbf{1 2 a}, \boldsymbol{b}$. To aminols 11a,b $(3 \mathrm{~g}, 13.7 \mathrm{mmol})$ dissolved in $n-\mathrm{BuOH}(75 \mathrm{~mL})$ and $i$ - $\operatorname{Pr}_{2}$ NEt (8.88 g, $68.7 \mathrm{mmol}$ ), 5-amino-4,6-dichloropyrimidine $(4.50 \mathrm{~g}, 27.5 \mathrm{mmol})$ was added. The mixtures were stirred at room temperature for $1 \mathrm{~h}$ and then slowly heated at $117^{\circ} \mathrm{C}$ with stirring for $48 \mathrm{~h}$. The cooled solutions were evaporated to dryness, taken up in $\mathrm{CH}_{2} \mathrm{Cl}_{2}$, washed with brine, and dried over anhydrous $\mathrm{Na}_{2} \mathrm{SO}_{4}$. The crude residues were then submitted to column chromatography to separate the excess of aminopyrimidine from adducts $\mathbf{1 2 a}$, b which were isolated in $79 \%$ yield for both regioisomeric compounds. Yields improvements are around 30\% with respect to previous method. The analytical and spectroscopic data are in full accordance with those reported in [13].

4.2. Construction of the Purine Nucleosides $\mathbf{1 3 a} \boldsymbol{a}, \boldsymbol{b}$. A solution of pyrimidine derivatives $\mathbf{1 2 a}, \mathbf{b}(3.50 \mathrm{~g}, 9.8 \mathrm{mmol})$ in triethyl orthoformate $(30 \mathrm{~mL})$ is stirred at room temperature until the starting material has been completely formulated (TLC monitoring) usually in 3-4 h. A catalytic amount of $p \mathrm{TsOH}$ was added afterwards and the reaction was stirred at room temperature for 5 days. After this period of time, the excess orthoformate was hydrolyzed in $24 \mathrm{~h}$ by adding water and the 
TABLE 2: Cytotoxicity and antiviral activity of compounds 14a,b and 16a,b in HEL cell cultures.

\begin{tabular}{|c|c|c|c|c|c|c|}
\hline \multirow[b]{2}{*}{ Compound } & \multirow{2}{*}{$\begin{array}{c}\mathrm{MCC}^{\mathrm{a}} \\
(\mu \mathrm{g} / \mathrm{mL})\end{array}$} & \multicolumn{5}{|c|}{$\mathrm{MIC}^{\mathrm{b}}(\mu \mathrm{g} / \mathrm{mL})$} \\
\hline & & $\begin{array}{l}\text { HSV-1 } \\
\text { (KOS) }\end{array}$ & $\begin{array}{c}\mathrm{HSV}-2 \\
(\mathrm{G})\end{array}$ & VV & VSV & HSV-1 TK-ACV ${ }^{\mathrm{r}}$ \\
\hline $14 \mathrm{aA}$ & 80 & $>16$ & $>16$ & $>16$ & $>16$ & $>16$ \\
\hline $14 \mathrm{aB}$ & $>400$ & $>400$ & $>400$ & $>400$ & $>400$ & $>400$ \\
\hline $14 \mathrm{aC}$ & 80 & $>16$ & $>16$ & $>16$ & $>16$ & $>16$ \\
\hline $14 \mathrm{aD}$ & 400 & $>80$ & $>80$ & $>80$ & $>80$ & $>80$ \\
\hline $14 \mathrm{bA}$ & 16 & $>3.2$ & $>3.2$ & $>3.2$ & $>3.2$ & $>3.2$ \\
\hline $14 \mathrm{bB}$ & $>400$ & $>400$ & $>400$ & $>400$ & $>400$ & $>400$ \\
\hline $14 \mathrm{bC}$ & 80 & $>16$ & $>16$ & $>16$ & $>16$ & $>16$ \\
\hline $14 \mathrm{bD}$ & 16 & $>3.2$ & $>3.2$ & $>3.2$ & $>3.2$ & $>3.2$ \\
\hline $16 \mathrm{aU}$ & $>400$ & $>400$ & $>400$ & $>400$ & $>400$ & $>400$ \\
\hline $16 \mathrm{aT}$ & $>400$ & $>400$ & $>400$ & $>400$ & $>400$ & $>400$ \\
\hline $16 b U$ & 400 & $>80$ & $>80$ & $>80$ & $>80$ & $>80$ \\
\hline $16 \mathrm{bT}$ & 400 & $>80$ & $>80$ & $>80$ & $>80$ & $>80$ \\
\hline Brivudine & $>400$ & 0.128 & 400 & 48 & $>400$ & $>400$ \\
\hline Ribavirin & $>400$ & $>400$ & 48 & 240 & $>400$ & $>400$ \\
\hline Acyclovir & $>400$ & 0.64 & 0.64 & $>400$ & $>400$ & 400 \\
\hline Ganciclovir & $>400$ & 0.096 & 0.16 & $>100$ & $>100$ & 12 \\
\hline
\end{tabular}

${ }^{a}$ Minimum cytotoxic concentration, required to cause a microscopically detectable alteration of normal cell morphology.

${ }^{\mathrm{b}}$ Minimum inhibitory concentration required to reduce virus-induced cytopathogenicity by $50 \%$.

TABLE 3: Cytotoxicity and antiviral activity of compounds $14 \mathbf{a}, \mathbf{b}$ and 16a,b in HeLa cell cultures.

\begin{tabular}{lcccc}
\hline \multirow{2}{*}{ Compound } & \multirow{2}{*}{$\mathrm{MCC}^{\mathrm{a}}(\mu \mathrm{g} / \mathrm{mL})$} & \multicolumn{3}{c}{$\mathrm{MIC}^{\mathrm{b}}(\mu \mathrm{g} / \mathrm{mL})$} \\
\hline 14aA & 80 & $>16$ & $>16$ & $>16$ \\
14aB & 400 & $>80$ & $>80$ & $>80$ \\
14aC & $\geq 16$ & $>16$ & $>16$ & $>16$ \\
14aD & 80 & $>16$ & $>16$ & $>16$ \\
14bA & $\geq 80$ & $>80$ & $>80$ & $>80$ \\
14bB & $\geq 80$ & $>80$ & $>80$ & $>80$ \\
14bC & $\geq 16$ & $>16$ & $>16$ & $>16$ \\
14bD & $\geq 80$ & $>80$ & $>80$ & $>80$ \\
16aU & 400 & $>80$ & $>80$ & $>80$ \\
16aT & $\geq 80$ & $>80$ & $>80$ & $>80$ \\
16bU & 400 & $>80$ & $>80$ & $>80$ \\
16bT & $\geq 80$ & $>80$ & $>80$ & $>80$ \\
\hline Brivudin & $>400$ & $>400$ & $>400$ & $>400$ \\
Ribavirin & $>400$ & 48 & 80 & 48 \\
(S)-DHPA & $>400$ & $>400$ & $>400$ & $>400$
\end{tabular}

${ }^{a}$ Minimum cytotoxic concentration, required to cause a microscopically detectable alteration of normal cell morphology.

${ }^{\mathrm{b}}$ Minimum inhibitory concentration required to reduce virus-induced cytopathogenicity by $50 \%$.

water phase extracted with $\mathrm{CH}_{2} \mathrm{Cl}_{2}$ and dried over anhydrous $\mathrm{Na}_{2} \mathrm{SO}_{4}$. After evaporation of the solvent, the residue was taken up with diisopropyl ether and few drops of ethyl acetate and the chloropurine derivatives 13a,b crystallized. Yields improvements are around $10 \%$ with respect to previous method. The analytical and spectroscopic data are in full accordance with those previously reported [13].
TABLE 4: Cytotoxicity and antiviral activity of compounds 14a,b and $\mathbf{1 6 a}, \mathbf{b}$ in Vero cell cultures.

\begin{tabular}{lcccccc}
\hline \multirow{2}{*}{ Compound $\mathrm{MCC}^{\mathrm{a}}(\mu \mathrm{g} / \mathrm{mL})$} & \multicolumn{5}{c}{$\mathrm{MIC}^{\mathrm{b}}(\mu \mathrm{g} / \mathrm{mL})$} \\
& & $\mathrm{PiV}$ & $\mathrm{RV}$ & $\mathrm{SV}$ & $\mathrm{CV}$ & $\mathrm{PTV}$ \\
\hline 14aA & 80 & $>16$ & $>16$ & $>16$ & $>16$ & $>16$ \\
14aB & 400 & $>80$ & $>80$ & $>80$ & $>80$ & $>80$ \\
$\mathbf{1 4 a C}$ & 80 & $>16$ & $>16$ & $>16$ & $>16$ & $>16$ \\
14aD & 400 & $>80$ & $>80$ & $>80$ & $>80$ & $>80$ \\
14bA & $\geq 400$ & $>80$ & $>80$ & $>80$ & $>80$ & $>80$ \\
14bB & 400 & $>80$ & $>80$ & $>80$ & $>80$ & $>80$ \\
14bC & 80 & $>16$ & $>16$ & $>16$ & $>16$ & $>16$ \\
14bD & 400 & $>80$ & $>80$ & $>80$ & $>80$ & $>80$ \\
16aU & 400 & $>80$ & $>80$ & $>80$ & $>80$ & $>80$ \\
16aT & 400 & $>80$ & $>80$ & $>80$ & $>80$ & $>80$ \\
16bU & 400 & $>80$ & $>80$ & $>80$ & $>80$ & $>80$ \\
16bT & 400 & $>80$ & $>80$ & $>80$ & $>80$ & $>80$ \\
\hline Brivudine & $>400$ & $>400$ & $>400$ & $>400$ & $>400$ & $>400$ \\
Ribavirin & $>400$ & 48 & 48 & 240 & 48 & 48 \\
(S)-DHPA & $>400$ & 48 & 240 & $>400$ & $>400$ & $>400$ \\
\hline
\end{tabular}

${ }^{a}$ Minimum cytotoxic concentration, required to cause a microscopically detectable alteration of normal cell morphology.

${ }^{\mathrm{b}}$ Minimum inhibitory concentration required to reduce virus-induced cytopathogenicity by $50 \%$.

4.3. Syntheses of the Adenine Derivatives $\mathbf{1 4 a}, \boldsymbol{b}(\boldsymbol{A}-\boldsymbol{D})$. Solutions of chloro-nucleosides 13a,b $(50 \mathrm{mg}, 0.14 \mathrm{mmol})$ in $\mathrm{MeOH}(3 \mathrm{~mL})$ were saturated with ammonia or other gaseous amines and kept in a sealed tube at $50^{\circ} \mathrm{C}$ for $24 \mathrm{~h}$. In the case of liquid amines, an excess ( 40 equiv.) was added to the solutions. The solutions are then cooled and concentration of the solutions afforded oily residues from which the amino 
derivatives were crystallized from proper solvents. The yields of the amino nucleosides $14 \mathbf{a}, \mathbf{b}(\mathbf{A}-\mathbf{D})$ were determined by hplc analyses and are generally excellent (92-99\%). The hplc analyses were performed according to the reported conditions by injecting $5 \mu \mathrm{L}$ of the alcoholic solutions after cooling them to ambient and using external standard method for quantitative determinations [13].

4.4. Syntheses of the Thio-Derivatives $14 a, b S$. The chloronucleosides 13a,b (25 mg, $0.07 \mathrm{mmol})$ were dissolved in $2 \mathrm{~mL}$ of a $1: 2$ EtOH : $\mathrm{H}_{2} \mathrm{O}$ solution. $\mathrm{Na}_{2} \mathrm{~S}(13 \mathrm{mg}, 0.23 \mathrm{mmol})$ was added and the mixtures were heated at reflux for $2 \mathrm{~h}$. After this period of time, the $\mathrm{pH}$ is adjusted at neutrality upon treatment with a $10 \%$ acetic acid solution. Upon cooling, white crystals separated off and were filtrated. The NMR spectra reported below refer to the major tautomer II.

14aS, white crystals from ethanol, m.p. $205-206^{\circ} \mathrm{C}$ (dec.). IR $\left(\mathrm{cm}^{-1}\right): \quad v_{\mathrm{OH}} 3314, \quad v_{\mathrm{C}=\mathrm{N}} 1607,1591 .{ }^{1} \mathrm{H}-\mathrm{NMR}(\delta$, $\left.\mathrm{CD}_{3} \mathrm{COCD}_{3}\right): 2.65\left(\mathrm{~m}, 2 \mathrm{H}, \mathrm{CH}_{2}\right) ; 4.54(\mathrm{dd}, J 10,3 \mathrm{~Hz}, 1 \mathrm{H}$, $\mathrm{H} 4$ isox.); 4.64 (m, 3H, CH-OH); 5.31 (m, 1H, CH-N); 5.81 (dd, J 10, $3 \mathrm{~Hz}, 1 \mathrm{H}, 5$ isox.); 7.45 (m, 3H, arom.); 7.85 (m, 2H, arom.); 8.78 (s, $1 \mathrm{H}, \mathrm{CH}=\mathrm{N}) ; 8.83$ (s, $1 \mathrm{H}, \mathrm{CH}=\mathrm{N}) .{ }^{13} \mathrm{C}-\mathrm{NMR}$ $\left(\delta, \mathrm{CD}_{3} \mathrm{COCD}_{3}\right): 38.5,61.7,62.0,75.2,89.7,127.1,128.7,128.8$, 130.0, 139.7, 146.0, 151.3, 157.0, 172.5. Elemental analysis: calcd. For $\mathrm{C}_{17} \mathrm{H}_{15} \mathrm{~N}_{5} \mathrm{O}_{2} \mathrm{~S}(\mathrm{MW}=353.33) \mathrm{C}, 57.78 ; \mathrm{H}, 4.28 ; \mathrm{N}, 19.82$. Found: C, 57.8; H, 4.3; N, 20.0.

$14 \mathrm{bS}$, white crystals from ethanol, m.p. $208-210^{\circ} \mathrm{C}$ (dec.). IR $\left(\mathrm{cm}^{-1}\right): v_{\mathrm{OH}} 3284, v_{\mathrm{C}=\mathrm{N}} 1607,1590 .{ }^{1} \mathrm{H}-\mathrm{NMR}(\delta$, $\left.\mathrm{CD}_{3} \mathrm{COCD}_{3}\right): 2.58\left(\mathrm{~m}, 2 \mathrm{H}, \mathrm{CH}_{2}\right) ; 4.50(\mathrm{dd}, J 10,3 \mathrm{~Hz}, 1 \mathrm{H}$, $\mathrm{H} 4$ isox.); 4.62 (m, 3H, CH-OH); 5.25 (m, 1H, CH-N); 5.76 (dd, J 10, $3 \mathrm{~Hz}, 1 \mathrm{H}, 5$ isox.); 7.45 (m, 3H, arom.); 7.85 (m, 2H, arom.); $8.75(\mathrm{~s}, 1 \mathrm{H}, \mathrm{CH}=\mathrm{N}) ; 8.78(\mathrm{~s}, 1 \mathrm{H}, \mathrm{CH}=\mathrm{N}) .{ }^{13} \mathrm{C}-\mathrm{NMR}$ $\left(\delta, \mathrm{CD}_{3} \mathrm{COCD}_{3}\right): 37.3,60.5,60.8,74.0,88.5,125.9,127.6$, $127.7,128.8,142.0,144.8,150.1,155.9,171.5$. Elemental analysis: calcd. For $\mathrm{C}_{17} \mathrm{H}_{15} \mathrm{~N}_{5} \mathrm{O}_{2} \mathrm{~S}(\mathrm{MW}=353.33) \mathrm{C}, 57.78 ; \mathrm{H}, 4.28 ; \mathrm{N}$, 19.82. Found: C, 57.7; H, 4.2; N, 19.9.

4.5. Syntheses of the Isocyanate Adducts $\mathbf{1 5 a}, \boldsymbol{b}$. To solutions of aminols 11a,b ( $3 \mathrm{~g}, 13.7 \mathrm{mmol})$ in anhydrous DMF $(15 \mathrm{~mL})$ at $-20^{\circ} \mathrm{C}$, solutions of the proper isocyanates $\mathbf{U}, \mathbf{T}(16.4 \mathrm{mmol})$ in anhydrous benzene were added dropwise with stirring in anhydrous nitrogen atmosphere and in the presence of 6 MS $4 \AA$. After keeping for one night $(12 \mathrm{~h})$ at r.t., the solutions were filtered and solvent was removed under reduced pressure. The residues were submitted to column chromatography to isolate the compounds $\mathbf{1 5 a} \mathbf{a}, \mathbf{b}$ in $82 \%$ yields and purified through crystallization from ethanol. The analytical and spectroscopic data are in full accordance with those previously reported [13].

4.6. Construction of the Uracil and Thymine Nucleosides 16a,b. Adducts 15a,b(U,T) (4 mmol) are suspended in $2 \mathrm{M} \mathrm{H}_{2} \mathrm{SO}_{4}$ $(25 \mathrm{~mL})$ solutions and gently refluxed for $3 \mathrm{~h}$. After cooling, the $\mathrm{pH}$ is adjusted to 7 with $\mathrm{NaHCO}_{3}$ and the water phase extracted with dichloromethane. Evaporation of the dried organic phase afforded the uracil or thymine nucleosides 16a,b(U,T) (91-95\%, +20\%) which were purified by simple crystallization.
4.7. Antiviral Activity and Cytotoxicity. The synthesized compounds were evaluated for their antiviral and cytotoxicity activity against herpes simplex virus type 1 (HSV-1, strain KOS), herpes simplex virus type 2 (HSV-2, strain G), vaccinia virus (VV), vesicular stomatitis virus (VSV), HSV-1 (KOS) thymidine kinase-deficient $\left(\mathrm{TK}^{-}\right) \mathrm{ACV}^{\mathrm{r}}$ in HEL cell cultures, VSV, Coxsackie (CV) virus B4 and respiratory syncytial virus (RSV) in HeLa cell cultures, parainfluenza-3 virus (PiV), reovirus-1 (RV), sindbis virus (SV), CV, and Punta Toro virus (PTV) in Vero cells cultures.

The antiviral activity was monitored by plaque reduction. The compounds were first dissolved in $100 \%$ DMSO and then diluted with EMEM-5 (Eagle's minimal essential medium) before use. The maximum final concentration of DMSO added to the cell cultures was $0.5 \%$ at the highest concentration of the compound and does not interfere with cell growth. The appropriate cells were seeded in 96-well plates at a density of $2 \times 10^{5}$ cells/well and were allowed to form confluent monolayers by incubating overnight in growth medium at $37^{\circ} \mathrm{C}$ with $5 \% \mathrm{CO}_{2}$ atmosphere. Monolayers were then inoculated with 100 CCID50 (1 CCID50 being the virus dose required to infect $50 \%$ of the cell cultures). After 1 hour of virus adsorption, residual virus was removed and replaced by cell culture medium (Eagle's minimal essential medium) containing various concentrations $(400,200,100$, and $50 \mu \mathrm{g})$ of the test compounds. Cultures were incubated at $37^{\circ} \mathrm{C}$ for $48 \mathrm{~h}$ and then strained with $0.1 \%$ crystal violet solution. Plaques were then enumerated and the $\mathrm{IC}_{50}$ values for the various drugs were determined. The activities of compounds 14a,b-16a,b were compared with those of brivudine, ribavirin acyclovir, and ganciclovir.

The cytotoxicity of all compounds was also evaluated. Briefly, HEL, HeLa, and Vero cells were seeded in 96-well plates; $24 \mathrm{~h}$ later increasing concentrations of the tested compounds were added to each well. After a further incubation of $24 \mathrm{~h}$ at $37^{\circ} \mathrm{C}$ in a humidified, $5 \% \mathrm{CO}_{2}$ atmosphere, the cells viability was evaluated by a commercial assay (CellTiter 96 Aqueous One Solution Assay, Promega Co., Madison WI), following the manufacturer's instructions. This assay is based on the principle that cells, at death, rapidly lose the ability to reduce MTS tetrazolium. At the end of the incubation time, the MTS-tetrazolium-based reagent was added to each well. After a further incubation of $1 \mathrm{~h}\left(37^{\circ} \mathrm{C}, 5 \% \mathrm{CO}_{2}\right.$ atmosphere), the absorbance of the samples was recorded at $490 \mathrm{~nm}$ using a 96-well spectrophotometer. The cytotoxic concentration $50 \%$ was calculated as the concentrations of the compounds 14a,b-16a,b required to cause $50 \%$ reduction of absorbance values. The antiviral and cytotoxicity data are reported in Tables 2, 3, and 4 [35].

\section{Conflict of Interests}

The authors declare that there is no conflict of interests regarding the publication of this paper.

\section{Acknowledgments}

Financial support by the University of Pavia, MIUR (PRIN 2011, CUP: F11J12000210001), and EUTICALS S.p.a., Viale 
Milano, 86/88-26900 Lodi, Italy, is gratefully acknowledged. The authors wish to thank the Fondazione Banca del Monte di Lombardia for a research grant. Thanks are also due to the Consorzio Interuniversitario Nazionale Metodologie e Processi Innovativi di Sintesi (CINMPIS) for research support. COST Action CM1004 "Synthetic Probes for Chemical Proteomics and Elucidation of Biosynthetic Pathways" is gratefully acknowledged.

\section{References}

[1] L. Agrofoglio and S. R. Challand, Acyclic, Carbocyclic and lNucleosides, Kluver Academic Publishers, Dordrecht, The Netherlands, 1998.

[2] M. T. Crimmins, "New developments in the enantioselective synthesis of cyclopentyl carbocyclic nucleosides," Tetrahedron, vol. 54, no. 32, pp. 9229-9272, 1998.

[3] T. Ueda, Chemistry of Nucleosides and Nucleotides, vol. 1, chapter 1, Plenum Press, New York, NY, USA, 1988, edited by L. B. Townsend.

[4] B. M. Trost, R. Madsen, S. D. Guile, and B. Brown, "Palladiumcatalyzed enantioselective synthesis of carbanucleosides," Journal of the American Chemical Society, vol. 122, no. 25, pp. 59475956, 2000.

[5] W. Ye and S. W. Schneller, " 5 '-methylaristeromycin and related derivatives," The Journal of Organic Chemistry, vol. 71, no. 22, pp. 8641-8643, 2006.

[6] R. Vince and M. Hua, "Synthesis and anti-HIV activity of carbocyclic $2^{\prime}, 3^{\prime}$-didehydro-2', $3^{\prime}$-dideoxy 2,6-disubstituted purine nucleosides," Journal of Medicinal Chemistry, vol. 33, no. 1, pp. 17-21, 1990.

[7] D. F. Ewing, N. E. Fahmi, C. Len, G. Mackenzie, and A. Pranzo, "Stereoisomeric pyrimidine nucleoside analogues based on the 1,3-dihydrobenzo[c] furan core," Journal of the Chemical Society, Perkin Transactions 1, no. 21, pp. 3561-3565, 2000.

[8] D. Egron, C. Périgaud, G. Gosselin et al., "1,3-Dihydrobenzo[c]furan nucleoside analogues: additional studies of the thymine derivative," Bioorganic and Medicinal Chemistry Letters, vol. 13, no. 24, pp. 4473-4475, 2003.

[9] L. Belmonte, P. Baré, M. M. E. de Bracco, and B. H. RuibalAres, "Reservoirs of HIV replication after successful combined antiretroviral treatment," Current Medicinal Chemistry, vol. 10, no. 4, pp. 303-312, 2003.

[10] P. Abeijòn, J. M. Blanco, F. Fernàndez, M. D. García, and C. Lòpez, "Synthesis of two precursors of heterocarbocyclic nucleoside analogues," European Journal of Organic Chemistry, vol. 2006, no. 3, pp. 759-764, 2006.

[11] M. D. García, O. Caamaño, F. Fernández, X. García-Mera, and I. Pérez-Castro, "Synthesis of purinyl and pyrimidinyl $1^{\prime}(\mathrm{N})$ homocarbanucleosides based on a 1-methylcyclopenta[c]pyrazole scaffold; part 2," Synthesis, no. 23, pp. 3967-3972, 2006.

[12] G. Romeo, U. Chiacchio, A. Corsaro, and P. Merino, "Chemical synthesis of heterocyclic-sugar nucleoside analogues," Chemical Reviews, vol. 110, no. 6, pp. 3337-3370, 2010.

[13] P. Quadrelli, R. Scrocchi, P. Caramella, A. Rescifina, and A. Piperno, "From cyclopentadiene to isoxazoline-carbocyclic nucleosides: A rapid access to biological molecules through nitrosocarbonyl chemistry," Tetrahedron, vol. 60, no. 16, pp. 36433651, 2004.

[14] P. Quadrelli, M. Mella, S. Carosso, B. Bovio, and P. Caramella, "A straightforward synthesis of isoxazoline-based carbocyclic nucleosides from 1,3-cyclohexadiene through nitrosocarbonyl chemistry," European Journal of Organic Chemistry, no. 36, pp. 6003-6015, 2007.

[15] S. C. Zimmermann, J. M. Sadler, G. Andrei, R. Snoeck, J. Balzarini, and K. L. Seley-Radtke, "Carbocyclic 5/-nor "reverse" fleximers. Design, synthesis, and preliminary biological activity," MedChem Comm, vol. 2, no. 7, pp. 650-654, 2011.

[16] G. W. Kirby, "Tilden Lecture. Electrophilic C-nitroso-compounds," Chemical Society Reviews, vol. 6, no. 1, pp. 1-24, 1977.

[17] B. E. Evans, K. E. Rittle, M. G. Bock et al., "Methods for drug discovery: development of potent, selective, orally effective cholecystokinin antagonists," Journal of Medicinal Chemistry, vol. 31, no. 12, pp. 2235-2246, 1988.

[18] P. Quadrelli, M. Mella, A. G. Invernizzi, and P. Caramella, “The mild oxidation of nitrile oxides affords a convenient entry to nitrosocarbonyl intermediates, versatile tools in organic syntheses," Tetrahedron, vol. 55, no. 34, pp. 10497-10510, 1999.

[19] P. Quadrelli, M. Mella, P. Paganoni, and P. Caramella, "Cycloadditions of nitrile oxides to the highly reactive $N$-acyl-2-oxa3- azanorborn-5-enes afford versatile cycloadducts and a convenient entry to highly functionalized derivatives," European Journal of Organic Chemistry, no. 14, pp. 2613-2620, 2000.

[20] A. D. Cohen, B.-B. Zeng, S. B. King, and J. P. Toscano, "Direct observation of an Acyl nitroso species in solution by timeresolved IR spectrocopy," Journal of the American Chemical Society, vol. 125, no. 6, pp. 1444-1445, 2003.

[21] M. G. Memeo, D. Dondi, B. Mannucci, F. Corana, and P. Quadrelli, "HNO made-easy from photochemical cycloreversion of novel 3,5-heterocyclic disubstituted 1,2,4-oxadiazole-4oxides," Tetrahedron, vol. 69, no. 35, pp. 7387-7394, 2013.

[22] N. Katagiri, Y. Yamatoya, and M. Ishikura, "The first synthesis of a 2I,3l-methano carbocyclic nucleoside," Tetrahedron Letters, vol. 40, no. 51, pp. 9069-9072, 1999.

[23] N. Katagiri, M. Nomura, H. Sato, C. Kaneko, K. Yusa, and T. Tsuruo, "Synthesis and anti-HIV activity of 9-[c-4,t-5-bis(hydroxymethyl)cyclopent-2-en-r-1-yl]-9H-adenine," Journal of Medicinal Chemistry, vol. 35, no. 10, pp. 1882-1886, 1992.

[24] S. M. Greenberg, L. O. Ross, and R. K. Robins, "Potential purine antagonists XXI. Preparation of some 9-phenyl-6-substituted purines," Journal of Organic Chemistry, vol. 24, no. 9, pp. 13141317, 1959.

[25] K. Murakami, T. Shirasaka, H. Yoshioka et al., "Escherichia coli mediated biosynthesis and in vitro anti-HIV activity of lipophilic 6-halo-2 ${ }^{\prime}, 3^{\prime}$-dideoxypurine nucleosides," Journal of Medicinal Chemistry, vol. 34, no. 5, pp. 1606-1612, 1991.

[26] A. R. Katritzky and C. W. Rees, Comp. Heteroc. Chem., vol. 5, Pergamon Press, Oxford, UK, 1984.

[27] I. Shcherbakova, J. Elguero, and A. R. Katritzky, “Tautomerism of heterocycles: condensed five-six, five-five, and six-six ring systems with heteroatoms in both rings," Advances in Heterocyclic Chemistry, vol. 77, pp. 51-113, 2000.

[28] P. Ü. Civcir, "A theoretical study of tautomerism of 6-thiopurine in the gas and aqueous phases using AM1 and PM3," Journal of Molecular Structure: THEOCHEM, vol. 535, pp. 121-129, 2001.

[29] A. R. Katritzky and C. W. Rees, "The structure, reactions, synthesis and uses of heterocyclic compounds," in Chemistry of Heterocyclic Compounds, A. J. Boulton and A. McKillop, Eds., vol. 3, pp. 107-116, Pergamon Press, Oxford, UK, 1984.

[30] B. Muray, J. Rifè, V. Branchedall, and R. M. J. Ortuño, "Stereoselective synthesis of novel types of cyclopropyl carbocyclic nucleosides containing quaternary stereogenic centers," The 
Journal of Organic Chemistry, vol. 67, no. 13, pp. 4520-4525, 2002.

[31] B. Muray, J. Rifè, V. Branchedall, and R. M. Ortuno, "Stereoselective synthesis of novel types of cyclopropyl carbocyclic nucleosides containing quaternary stereogenic centers," The Journal of Organic Chemistry, vol. 67, pp. 4520-4525, 2002.

[32] V. P. Rajappan, S. W. Schneller, S. L. Williams, and E. R. Kern, "The enantiomers of carbocyclic 5'-norguanosine: activity towards Epstein-Barr virus," Bioorganic and Medicinal Chemistry, vol. 10, no. 4, pp. 883-886, 2002.

[33] W. Qinpei and C. Simons, "Synthetic methodologies for Cnucleosides," Synthesis, no. 10, pp. 1533-1553, 2004.

[34] A. Piperno, M. A. Chiacchio, D. Iannazzo, and R. Romeo, "Synthesis and biological activity of phosphonated nucleosides: part 1. Furanose, carbocyclic and heterocyclic analogues," Current Medicinal Chemistry, vol. 13, no. 30, pp. 3675-3695, 2006.

[35] C. Xing, S. W. Schneller, S. Ikeda et al., "Synthesis and antiviral activity of 5 -deoxypyrazofurin," Journal of Medicinal Chemistry, vol. 36, no. 23, pp. 3727-3730, 1993. 

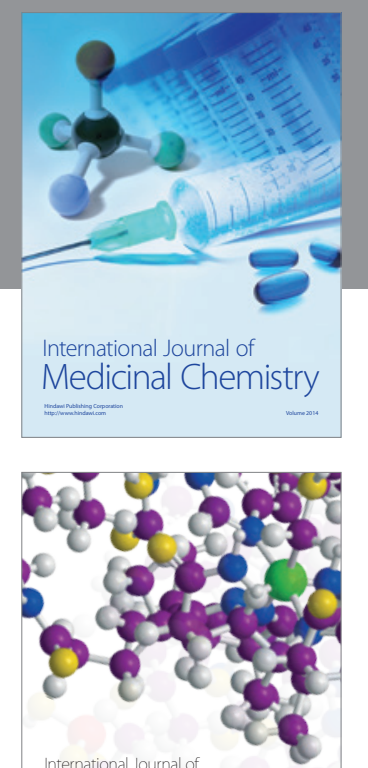

\section{Carbohydrate} Chemistry

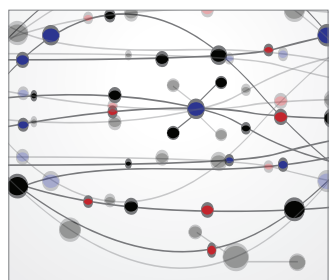

The Scientific World Journal
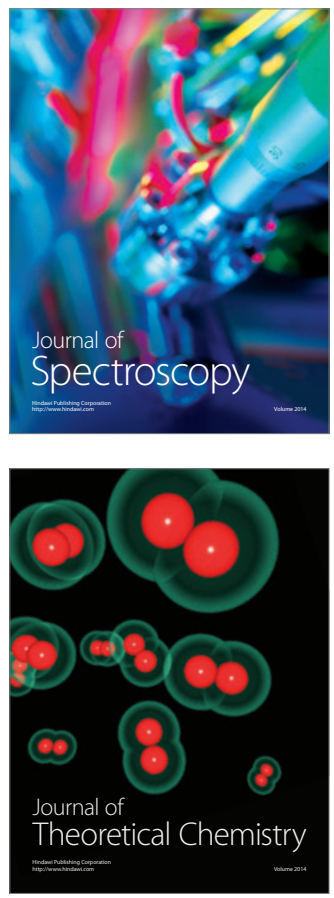
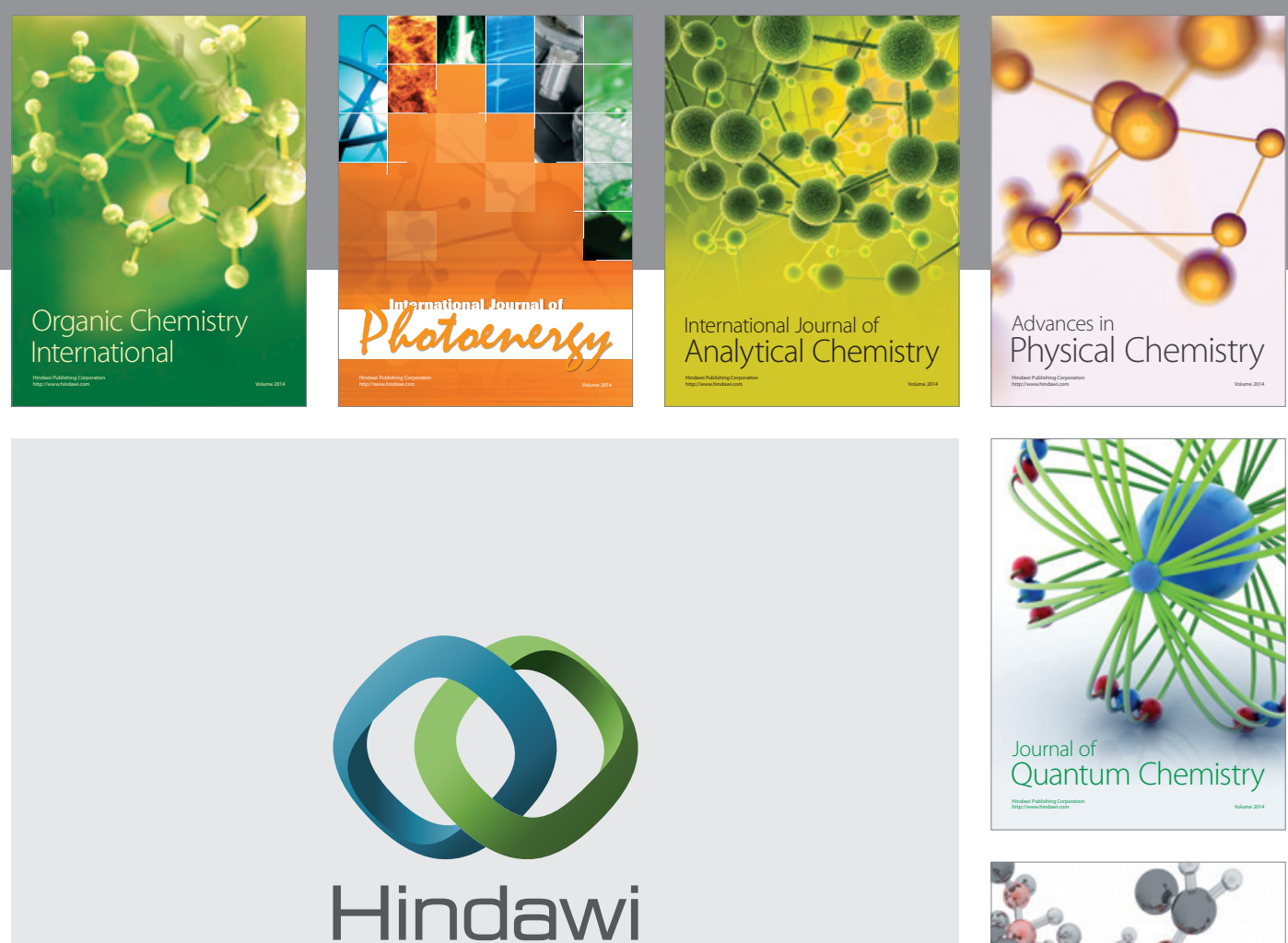

Submit your manuscripts at

http://www.hindawi.com

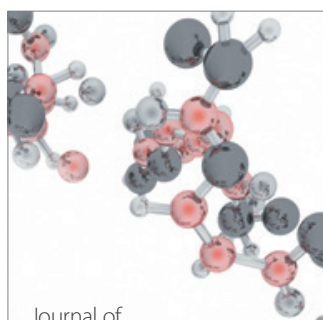

Analytical Methods

in Chemistry

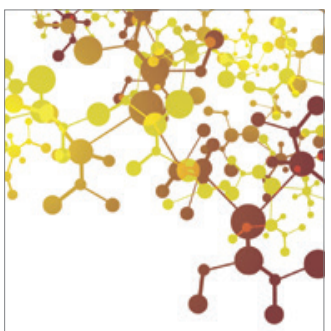

Journal of

Applied Chemistry

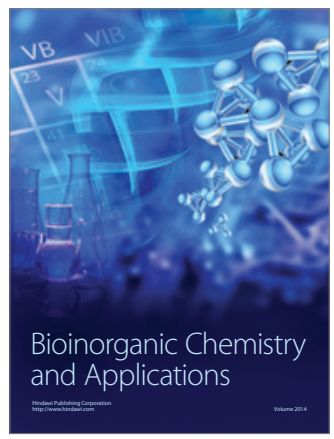

Inorganic Chemistry
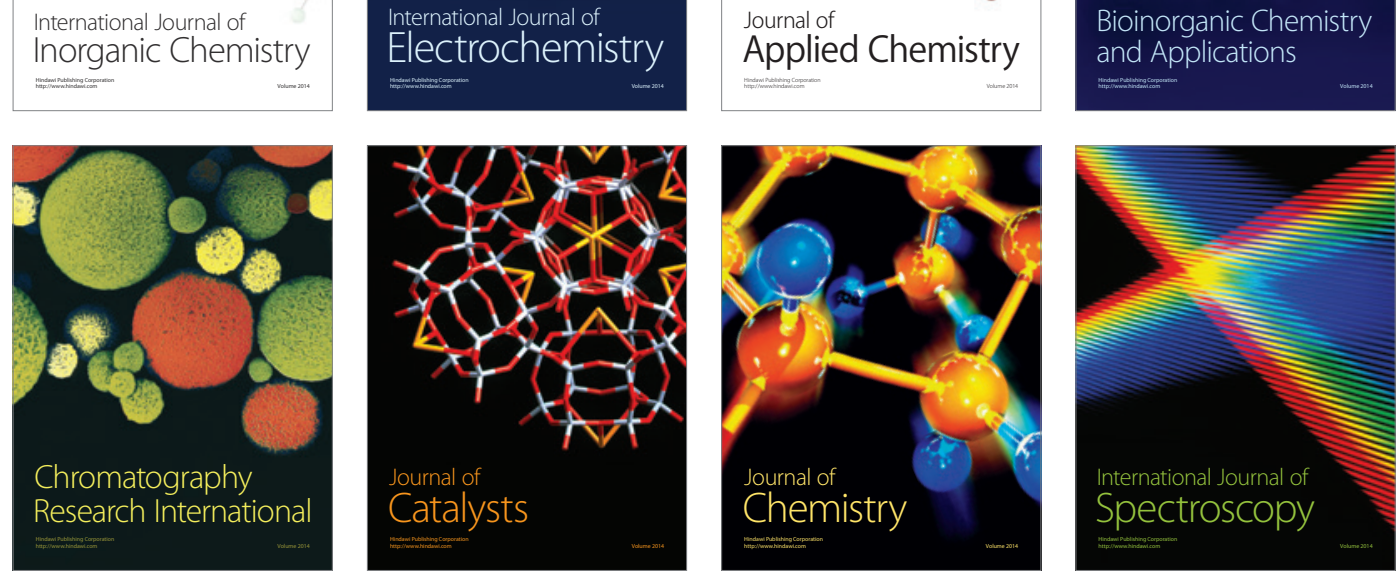